\title{
REGIONAL INTERNATIONAL COURTS IN SEARCH OF RELEVANCE: ADJUDICATING POLITICALLY SENSITIVE DISPUTES IN CENTRAL AMERICA AND THE CARIBBEAN
}

\author{
SALVATORE CASERTA*
}

\begin{abstract}
The Central American and the Caribbean Courts of Justice (CACJ and CCJ) are hybrid judicial institutions. While their Member States envisioned them as "EU-style" regional economic courts, they have explored the whole extension of their formally delegated functions and have developed peculiar expertise in matters relating to freedom of movement, human and fundamental rights, and other politically fraught issues. The article explains how two International Courts (ICs) seemingly established to build common markets have come to adjudicate high-stakes political disputes, which, ostensibly, have little to do with regional economic integration. The article posits that the scholarship on delegation to ICs is only partially able to provide an answer to this question. It, hence, suggests an alternative theoretical framework by relying on transnational field theory and reflexive sociology. The article demonstrates that, despite the rhetoric of their founding documents, both the CACJ and the CCJ were only partially established to pursue regional economic integration. Instead, both Courts were fashioned at the crossroads of several - and at times even conflictingforms of legality, power battles, professional interests, and visions of the world that shaped the Central American and Caribbean legal fields over time. Seen through the diachronic lens of the interests, ideologies, professional practices, and visions of the world of the actors inhabiting the Central American and Caribbean legal fields, the involvement of the two Courts in politically sensitive issues becomes less surprising, and-the

\footnotetext{
Copyright (C) 2017 Salvatore Caserta

Postdoctoral Research Fellow at iCourts, the Centre of Excellence for International Courts, Faculty of Law, University of Copenhagen. PhD, LLM, University of California, Berkeley, Faculty of Law. This research is funded by the Danish National Research Foundation Grant no. DNRF105 and conducted under the auspices of the Danish National Research Foundation's Centre of Excellence for
} International Courts (iCourts).
\end{abstract}


article argues - it constitutes part of a strategy of the judges to legitimize the two Courts vis-à-vis their peculiar institutional, political, and social environments.

\section{TABLE OF CONTENTS}

ABSTRACT 59

TABLE OF CONTENTS 60

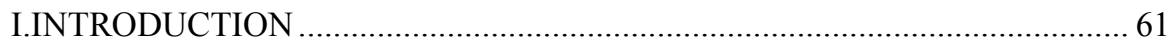

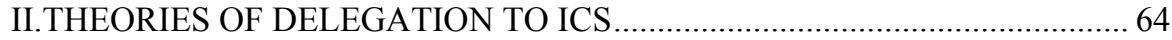

A. Principal-Agent (P-A) Theory ........................................................ 65

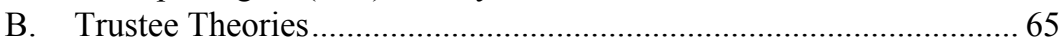

C. The Altered Politics Framework ………............................................. 66

III.THE POLITICALLY SENSITIVE JURISPRUDENCE OF THE TWO

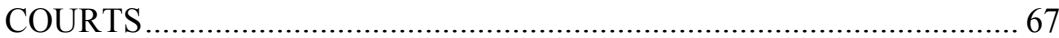

A. The Silent Rise of a Caribbean Human and Fundamental Rights Court: From Death Penalty to Indigenous Rights

B. The CCJ's Fundamental Rights Turn on the Court's Original Jurisdiction .

C. Litigating in the Shadow of the International Court of Justice: the CACJ as an Inter-State Court

D. Democratization through Judicial Means: the CACJ as a Regional Constitutional Court

IV.IMPLICATIONS OF THE EXPERIENCE OF THE CACJ AND OF THE CCJ

FOR THE THEORIES OF DELEGATION TO ICS

V.BRINGING THE SOCIAL BACK IN: EXPLAINING THE INVOLVEMENT OF THE CACJ AND OF THE CCJ WITH POLITICALLY SENSITIVE DISPUTES

A. The Protracted Geneses of the CACJ and the CCJ............................ 80

1. The Creation of the CCJ at the Crossroads of Decolonization and

Regional Integration 80

2. The Creation of the CACJ at the Crossroads of Pacification and Regional Integration

B. Career Paths of the Judges of the CACJ and of the CCJ and Influence in the Two Courts' Activities.

1. The Judges of the CCJ as a Microcosm of the Caribbean Legal Field 88

2. The CACJ as an Extension of the National Judiciaries................ 91

C. The Jurisprudence of the Two Courts as a Legitimization Strategy... 94

VI.CONCLUSIONS .95 


\section{INTRODUCTION}

The Central American Court of Justice (CACJ) and the Caribbean Court of Justice (CCJ) are the judicial organs of the Central American System of Regional Integration (SICA) and the Caribbean Community (CARICOM) respectively. The main function of these two Courts is to foster economic and legal integration in Central America and the Caribbean. The CACJ interprets and executes the Protocol of Tegucigalpa (the Protocol) and its complementary instruments. ${ }^{1}$ The CCJ has compulsory and exclusive jurisdiction to solve the disputes concerning the interpretation and application of the Revised Treaty of Chaguaramas (the RTC). ${ }^{2}$

Despite this, both the CACJ and the CCJ serve only partially as "EUstyle" regional economic courts, ${ }^{3}$ while they have explored the whole extension of their formally delegated functions, ${ }^{4}$ developing peculiar expertise in matters relating to freedom of movement, human and fundamental rights, and mega-politics. ${ }^{5}$ Among the Courts' most important cases, ${ }^{6}$ one may found judgments against Barbados for disrespecting the CARICOM immigration policies ${ }^{7}$ and for violating death penalty standards set up by international human rights treaties, ${ }^{8}$ against Belize for violating

1. Statute of the Central American Court of Justice art. 2, Dec. 11, 1992, available at http://portal.ccj.org.ni/ccjdemo/normativa/.

2. Revised Treaty of Chaguaramas art. 211, 2011, available at http://caricom.org/aboutcaricom/who-we-are/our-governance/the-revised-treaty/.

3. Both Courts have produced several rulings on trade disputes. See Salvatore Caserta, Regional Integration through Law-the Interplay Between De Jure and De Facto Supranationality in Central America and the Caribbean, 30 LEIDEN J. OF INT'L L. 579, 579, 586 (2017).

4. In addition to its Community Law competencies entrenched in the Court's Original Jurisdiction (OJ), the CCJ has also an Appellate Jurisdiction (AJ), which aims at replacing the Judicial Committee of the Privy Council (JCPC) as the court of last resort of those Caribbean States that were once British colonies. In the AJ, the CCJ rules over criminal and civil matters and it is competent to interpret the constitutions of those states that have ratified such a jurisdiction. See Derek O'Brien \& Sonia Foadi, CARICOM and its Court of Justice, 37 COMM. LAw WORLD REV. 334, 334 (2008). Similarly, besides being an EU-style Community Court, the CACJ is empowered to rule over inter-state conflicts, separation of powers disputes between the constitutional organs of the SICA Member States and as an arbitral tribunal. KATIN N. MetCAlF \& IOANNis PAPAgEORgIOU, Regional INTEGRATION AND COURTS OF JUSTICE 55 (2005).

5. Throughout the paper, mega-politics is understood as: "matters of outright and utmost political significance that often define and divide the whole polities." Ran Hirschl, The Judicialization of MegaPolitics and the Rise of Political Courts, 11 ANN. REV. POL. SCI. 93, 93 (2008).

6. The judgments of both the CACJ and the CCJ are available on the two Courts' websites. http://www.caribbeancourtofjustice.org/judgments-proceedings and http://portal.ccj.org.ni/ccj/ expedientes.

7. Shanique Myrie v. Barbados, OA 002, ๆ 101 (CCJ, 2012).

8. See generally Attorney General of Barbados v. Joseph and Boyce, CV 2 (CCJ, 2006). 
indigenous property rights, ${ }^{9}$ and, finally, against the Parliament of Nicaragua for pursuing a soft coup d'état against then-President Enrique Bolaños. ${ }^{10}$

Although not unique in the landscape of International Courts (ICs) outside Europe ${ }^{11}$ the involvement of the CACJ and of the CCJ into politically sensitive cases is theoretically puzzling. Like other regional organizations, the CARICOM and the SICA have only partially progressed towards their established goals of regional economic integration and the barriers to intra-regional trade have not been systematically challenged before the two Courts yet. Moreover, adjudicating high-stakes political disputes is not entirely in sync with what the Governments of the SICA and CARICOM States expect from the two Courts. These rulings also clash with the reluctance of Central American and Caribbean national courts to deal with such topics in their legal systems. Finally, the involvement of recently established ICs into politically fraught disputes challenges several existing theories that posit that these institutions shall adopt particular legal and extralegal strategies when ruling in highly sensitive disputes in order to avoid political pushbacks. ${ }^{12}$

The primary goal of this article is to explain how two ICs seemingly established to build common markets and to enforce trade liberalization have come to rule on high-stakes political disputes, which, ostensibly, have little to do with regional economic integration and are not entirely in line with the preference of the two Courts' Member States. In so doing, the article shows that the scholarship on delegation to ICs is only partially able to account for the Central American and Caribbean experiences. The article, hence, suggests an alternative explanation by relying on the theoretical tools provided by transnational field theory and reflexive sociology. ${ }^{13}$ Through this theoretical framework, the article demonstrates that, despite the rhetoric

9. See Maya Leaders Alliance et al. v. Attorney General of Belize, 366, \126-27 (CCJ, 2015).

10. See generally Ingeniero Enrique Bolaños Geyer v. Asamblea Nacional de la República de Nicaragua, CACJ n. 69-01-03-01-2005 (CACJ, 2005).

11. Both the Economic Community of West Africa Court of Justice (ECOWAS Court) and the East African Court of Justice (EACJ) have recently expanded their jurisdiction to encompass human rights. See Karen J. Alter, et al., A New International Human Rights Court for West Africa: The ECOWAS Community Court of Justice, 107 AM. J. INT'L L. 737, 737 (2013). James T. Gathii, Mission Creep or a Search for Relevance: The East African Court of Justice's Human Rights Strategy, 24 DuKE J. COMP. \& INT'L L. 249, 250 (2013).

12. Karen J. Alter, Agents or Trustees? International Courts in their Political Context, 14 EUR. J. INT'L REL. 33, 33 (2008). Mikael R. Madsen, The Protracted Institutionalization of the Strasbourg Court: From Legal Diplomacy to Integrationist Jurisprudence, in THE EUROPEAN COURT OF HuMAN RightS BETWEEN LAW AND POLITICS (2011).

13. Mikael R. Madsen \& Yves Dezalay, The Force of Law and Lawyers: Pierre Bourdieu and the Reflexive Sociology of Law, 8 ANN. REV. L. Soc. SCI. 433, 433 (2012). Mikael R. Madsen, Sociological Approaches to International Courts, in THE OXFORD HANDBOOK OF INTERNATIONAL ADJUDICATION 400 (2014). 
of their founding documents, both the CACJ and the CCJ were only partially established to pursue regional economic integration. Instead, both Courts were fashioned at the crossroads of several - and at times even conflicting forms of legality, power relations, professional interests, and visions of the world that have characterized the Central American and Caribbean legal fields over time.

The CACJ was established, and then controlled, by a close network of legal professionals - the Presidents of the Supreme Courts of the Central American States - whose main goal was to pacify and democratize Central America by legal and judicial means. The CCJ emerged out of the professional and ideological struggles fought by two elites of Caribbean lawyers in the shadow of the process of Caribbean decolonization from the United Kingdom. These two groups are a transnational power elite of English-educated Caribbean lawyers, who have played a double role in the struggle for Caribbean independence and in fostering the persistence of some of the legal aspects of British colonialism, and a younger generation of Caribbean-trained lawyers, willing to equip the CARICOM with the legal and institutional tools to throw the Caribbean into the new global economy at the end of the Cold War. ${ }^{14}$

Seen through the diachronic lens of the interests, ideologies, professional practices, and visions of the world of the actors inhabiting the Central American and Caribbean legal fields, the involvement of the two Courts in politically sensitive issues becomes less surprising. I, therefore, argue that this judicial behavior constitutes part of a strategy of the judges to legitimize the two Courts vis-à-vis their peculiar institutional, political, and social contexts. In particular, the two Courts did not limit themselves to develop some kind of formal and neutral legal rationality à l'européenne. Conversely, they aimed at producing substantively thick regional legal systems in order to make themselves relevant in the eyes of the major stakeholders in their fields of operation.

The article relies on 63 qualitative interviews with key stakeholders of the SICA and the CARICOM. ${ }^{15}$ The interview-based research is informed by the reflexive sociology of law and is aimed at understanding institutional and legal developments from the perspective of the agents surrounding the two Courts. ${ }^{16}$ For this purpose, the heuristic notion of the field proved to be

14. See generally Salvatore Caserta \& Mikael R. Madsen, Between Community Law and Common Law: The Rise of the Caribbean Court of Justice at the Intersection of Regional Integration and PostColonial Legacies, 79 LAW \& CONTEMP. PROBS. 89, 89 (2016).

15. The interviews were conducted during three field trips in Trinidad and Tobago, Barbados, Guyana, Nicaragua, and El Salvador between 2013 and 2014. See infra Appendix n. 1.

16. See generally Madsen \& Dezalay, supra note 13. 
a very helpful research tool. Framing the social space surrounding the two Courts in terms of network of objective (adversarial) relations over the meaning and purpose of these two institutions allowed me to capture the social continuities (and discontinuities) in the construction of professional practices and interests as well as visions of the world around the two Courts. $^{17}$ In this regard, the collective-relational biographies of the stakeholders of the Central American and Caribbean legal fields provided key evidence. ${ }^{18}$ By using the agents surrounding the two Courts as a vantage point, the article unveils the hierarchical structures in which individuals and groups operate, thus, objectivizing the socio-political dynamics and the very interests at stake concerning both the CACJ and the CCJ.

The remainder of the article proceeds as follow. Section II examines the theories of the delegation to ICs and formulates several hypotheses on the judicial behavior of the two Courts that will be empirically tested through the article. Section III presents the high-stakes political rulings decided by the two Courts. These are chiefly concerned with freedom of movement and human and fundamental rights in the Caribbean and inter-state conflicts and other politically sensitive issues in Central America. Section IV analyzes this case-law in the light of the hypotheses set forth in Section II, assessing the virtues and the limits of the existing theories of delegation to ICs. Here, the article shows that each theory alone does not fully explain the Central American and Caribbean experiences. Consequently, Section V offers an alternative explanation by providing a trans-historical and contextual analysis of the creation and of the professional interests, ideologies, and practices of the main stakeholders of the Caribbean and Central American legal fields. In so doing, the article shows that both Courts were only partially established to pursue regional economic integration, while they were also envisaged as tools to pacify Central America and to complete the process of Caribbean decolonization from the United Kingdom. This section concludes by arguing that the involvement of the two Courts in politically sensitive issues is part of an attempt of the judges of the two Courts to legitimize these institutions vis-à-vis their peculiar socio-political contexts. Section VI concludes by summarizing the main arguments of the paper.

\section{THEORIES OF DELEGATION TO ICS}

Why have the CACJ and the CCJ pushed themselves to the limits of their mandates, making themselves known as tribunals willing to deal with politically sensitive issues rather than limiting themselves to the "safer" role

17. Id. at 439

18. See id. for an account of collective biographies. 
of regional economic courts? Theories of delegation to ICs would answer this question in at least three different ways. For these theories, ICs are: agents of states, ${ }^{19}$ trustees, ${ }^{20}$ and actors that alter national, regional, and international politics. ${ }^{21}$

\section{A. Principal-Agent (P-A) Theory}

For P-A theorists, delegation of power to an IC: "is a conditional grant of authority from a principal [a state] to an agent [an IC] that empowers the latter to act on behalf of the former. This grant of authority is limited in time or scope and can be revocable by the principal." 22 In this view, ICs are essentially ineffectual at forcing compliance with decisions that do not conform to the interests of their principals. Different from national Supreme Courts - which are backed up by the coercive power of the state-ICs lack formal means for compelling states to comply with their decisions. ${ }^{23}$

This, in turn, means that the principals maintain a high degree of control over the ICs they establish. Principals, in fact, decide: the appointment of the judges, the amount of powers delegated to them, and, in most cases, even their finances. As Paul Stephan puts it: "Knowing that they can be replaced, the members of the tribunal have an incentive not to do anything that will upset the countries with nominating authority." 24

Hypothesis \#1: the CACJ and the CCJ would be expected to comply with the interests of the delegating states, which would be estimated to "punish" the two Courts for not doing so.

\section{B. Trustee Theories}

Under Trustee Theories, ICs enjoy a certain degree of autonomy from the states as these delegate powers: "to harness the authority of the Trustee so as to enhance the legitimacy of political decision-making." 25 Four

19. See generally Mark A. Pollack, The engines of European integration: Delegation, AGENCY, AND AGENDA SETTING IN THE EU (2003).

20. Laurence R. Helfer \& Anne-Marie Slaughter, Toward a Theory of Effective Supranational Adjudication, 107 YALE L. J. 273, 274 (1997); Alter, supra note 12, at 37.

21. See generally Karen J. Alter, The New Terrain of InTERnAtional Law: Courts, POLITICS, RigHTS (2013).

22. Darren G. Hawkins et al., Delegation Under Anarchy: States, International Organizations and Principal-Agent Theory, in DELEGATION AND AGENCY IN INTERNATIONAL ORGANIZATIONS 1, 7 (Darren G. Hawkins et al. eds., 2006).

23. See generally Geoffrey Garrett \& Barry Weingast, Ideas, Interests, and Institutions: Constructing the EC's Internal Market, in IDEAS AND FOREIGN POLICY 173 (Judith Goldstein \& Robert O. Keohane eds., 1993).

24. Paul B. Stephan, Courts, Tribunals and Legal Unification - The Agency Problem, 3 CHI. J. INT.L L. 333, 337 (2002).

25. According to Alter, trustees are: “1) selected because of their personal reputation; 2) given 
conditions must be met for an IC to avoid state control: i) non-compliance disputes with the treaties must be regularly filed before the IC; ii) the IC must produce defensible rulings; iii) states shall give precedence to the reasons given by the IC in its legal reasoning; and iv) the IC's rulings must trigger the interest of "compliance constituencies." 26 However, as posited by Karen J. Alter: "should a Trustee stray beyond what the power elite or body politic can accept, the option of removing a Trustee or eliminating the office altogether remains." 27

A slightly different version of Trustee Theory is constituted by the Constrained Independence Approach, according to which states allow ICs to rule against their interests only when these decisions maximize the long-term value of the treaty commitments to all parties. This, however, does not mean that ICs are completely independent. States, in fact, can use refined mechanisms to limit the potential judicial overreaching and to define the "strategic space" in which ICs operate. ${ }^{28}$

Hypothesis \#2: the CACJ and the CCJ would be expected to provide ambitious interpretations of their treaties only when these are in line with the overarching and long-term interests of the states or of other key stakeholders of their systems.

\section{The Altered Politics Framework}

Under the Altered Politics Framework, ICs expand the power of states and of national actors. ${ }^{29}$ The specific institutional features of the so-called "New-Style ICs" (i.e. compulsory jurisdiction and private access) allow nonstate actors to initiate litigation, thus increasing the power of ICs and transforming these institutions into strategic tools for "compliance constituencies" to pursue their interests and goals. ${ }^{30}$ Private parties' participation in international litigation, thus, merges domestic and international understanding of legality by making sure that compliance with international law becomes consistent with the respect of domestic laws. In the words of Alter: "ICs help alter state policy by using their institutional position to aid actors inside and outside of states that share the objectives

independent authority to make decisions according to their best judgment or professional criteria; and 3) empowered to act on behalf of a beneficiary." Alter, supra note 12, at 35 .

26. Alec Stone Sweet \& Thomas L. Brunell, Trustee Courts and the Judicialization of International Regimes: the Politics of Majoritarian Activism in the European Convention on Human Rights, the European Union, and the World Trade Organization, 1 J.L. \& CTS., 62-63 (2013).

27. Alter, supra note 12 , at 44.

28. Laurence R. Helfer \& Anne-Marie Slaughter, Why States Create International Tribunals: A Response to Professors Posner and Yoo, 93 CAL. L. REV. 899, 904-05 (2005).

29. ALTER, supra note 21.

30. ALTER, supra note 21, at 19-20. 
inscribed into the law." 31 The conditions for this to occur are that: i) litigants size the IC; ii) national actors care about legality; iii) legal entrepreneurs invoke the IC and contribute to build compliance constituencies; and iv) international rules are supported by national actors. ${ }^{32}$

Hypothesis \#3: the CACJ and the CCJ would be expected to be seized by constituencies willing to pursue political objectives which are not reachable domestically. States will play along as long as powerful domestic elites support international norms.

In brief, the three approaches presented above provide theoretical entry points for explaining why states create ICs and why ICs behave in certain ways. P-A theory chiefly focuses on how the self-interest of states operates as a constraint on ICs. Conversely, Trustee Theory and the Altered Politics Framework emphasize the conditions under which ICs may be able to overcome constraints and avoid political pushbacks.

\section{THE POLITICALLY SENSITIVE JURISPRUDENCE OF THE TWO COURTS}

This section presents the politically sensitive rulings of the CACJ and of the CCJ. As to the CCJ, these chiefly regard freedom of movement within the CARICOM in the Original Jurisdiction (OJ) and human rights in the Appellate Jurisdiction (AJ). The cases of the CACJ are different, as they mostly regard inter-state conflicts and separation of powers disputes between the constitutional organs of the SICA's Member States.

A. The Silent Rise of a Caribbean Human and Fundamental Rights

Court: From Death Penalty to Indigenous Rights

The CCJ has dealt with politically sensitive issues mainly in its AJ, where the Court is aimed at replacing the appeals to the JCPC in London as the apex judicial institution for those countries of the Caribbean that have ratified this jurisdiction through constitutional amendments (hitherto, Barbados, Guyana, Belize, and Dominica).

Perhaps the most important of these cases was The Attorney General of Barbados and others $v$ Joseph and Boyce. ${ }^{33}$ In this case, the CCJ was called to rule over the constitutionality of the mandatory death penalty for murder in Barbados. In addition, the Court touched upon other important issues, such as its relationship with the JCPC and the effects of unincorporated

\footnotetext{
31. ALTER, supra note 21, at 20.

32. ALTER, supra note 21, at 62 .

33. Attorney General of Barbados v. Joseph and Boyce, CV 2 (CCJ, 2006).
} 
international treaties in countries with a dualist tradition of international law. ${ }^{34}$

The case had huge political connotations. Since 1994-when the JCPC reversed its jurisprudence on capital punishment, establishing that a prolonged delay of more than five years in carrying out a death sentence constituted "inhuman and degrading punishment"35 - the Caribbean countries were in conflict with the English Court. ${ }^{36}$ The provisions of many international human rights treaties of which the Caribbean States were signatories, in fact, held that, in cases of appeals to an international organ by death row inmates, the national judiciaries were required to suspend the execution until a decision on the merit would be reached at the international level. The procedures before international human rights instruments, however, were often lengthy, causing delays in the execution of death row inmates by national authorities. The JCPC's new jurisprudence on the death penalty, hence, placed the Caribbean countries in a position where they faced the dilemma of either being forced to violate the five years term for executing death row inmates set up by the same JCPC or of being in violation of the international human rights treaties they were members of. ${ }^{37}$

This situation caused a significant upheaval in the Caribbean region: Jamaica, Guyana, and Trinidad and Tobago denounced the international human rights instruments they were part of; almost at the same time, the CCJ was established with an appellate jurisdiction aimed at replacing the JCPC at the apex of the judicial systems of several Caribbean countries. ${ }^{38}$

The decision of the CCJ in Joseph and Boyce is revealing of the Court's willingness to deal with politically sensitive issues. To begin with, the CCJ rejected the dualist argument put forward by the Barbadian Government, according to which, even if ratified by the executive, international treaties form no part of domestic law, unless they have been incorporated by the legislature. ${ }^{39}$ At the same time, the CCJ did not endorse the alternative view offered by the JCPC, which claimed that ratified but unincorporated international treaties were directly effective and applicable. ${ }^{40}$ Here, the Court

34. In the specific case, on the effect of the IACHR in Barbados, IACHR was only signed and ratified by the Barbadian officers but not transplanted into national law by the Parliament.

35. Pratt and Morgan v. the Attorney General of Jamaica, 2. A.C., Decision on Appeal from the Court of Appeal of Jamaica, 35 (1994).

36. At that point, the JCPC was - and for many still is - the apex court of many Caribbean States.

37. Laurence R. Helfer, Overlegalizing Human Rights: International Relations Theory and the Commonwealth Caribbean Backlash against Human Rights Regimes, 102 COLUM. L. REV. 1832, 186365 (2002).

38. Caserta \& Madsen, supra note 14.

39. Attorney General of Barbados v. Joseph \& Boyce, CV 2, ๆ 55-56 (CCJ, 2006).

40. The JCPC expressed this view in Lewis et al. v. Attorney General, 2 A.C., Decision on the 
borrowed a principle already developed by the Australian High Court, ${ }^{41}$ according to which unincorporated international treaties give rise to a "legitimate expectation" to the procedures established by such treaties. In the specific case in point, death row inmates would not be executed until reasonable time is allowed for the international systems to run their course. ${ }^{42}$ Accordingly, the CCJ granted Joseph and Boyce the right to have their petition to the Inter-American Human Rights System heard before Barbados could conduct their execution. ${ }^{43}$

Joseph and Boyce was followed by other important human and fundamental rights cases. One of these is Maya Leaders Alliance v. Attorney General of Belize, ${ }^{44}$ in which the CCJ was called to rule over a long-standing land rights dispute between the Belizean Government and the Mayan minorities of Southern Belize. This was another case in which the CCJ showed its willingness to become involved in politically sensitive issues. The CCJ upheld the constitutional rights of the Mayas against arbitrary deprivation of property as well as the right to protection of the law. ${ }^{45}$ In so doing, the Court reversed the traditional (and narrow) reading of the right to protection of the law, according to which this right merely encompassed access to independent and impartial courts. ${ }^{46}$ Conversely, the CCJ described the right to protection of the law in terms of a "broad spectrum right" that "includes not only access to the court... but also [access] to administrative tribunals with the power to affect constitutional rights or rights under the Constitution of an individual." 47 The CCJ not only acknowledged the existence of these rights, but also ruled that: "the right to protection of the law may, in appropriate cases, require the relevant organs of the state to take positive action in order to secure and ensure the enjoyment of basic

Appeal from the Court of Appeals of Jamaica, 51-52, 78 (2001). The relevant provision here was Article 4(6) of the American Convention on Human Rights, according to which: "Every person condemned to death shall have the right to apply for amnesty, pardon, or commutation of sentence, which may be granted in all cases. Capital punishment shall not be imposed while such petition is pending decision by the competent authority." The Court noted that some Caribbean countries had also ratified other international human rights instruments, such as the International Covenant on Civil and Political Rights (ICCPR) and the Optional Protocol to the ICCPR which protect the right to life. See also Maya Leaders Alliance et al. v. Attorney General of Belize, 366, 154 (CCJ, 2015).

41. See Minister for Immigration \& Ethnic Affairs v. Teoh [1995] HCA 20183 CLR 273. See also Matthew Groves, Treaties and Legitimate Expectations - The Rise and Fall of Teoh in Australia, 15 JUD'L. REV. 323, 323 (2010).
42. Joseph and Boyce, supra note 8 , at 11 .
43. Id. at 144 .
44. Maya Leaders Alliance, supra note 9.
45. Id. at 32 .
46. See id. at 39.
47. Id. at 49. 
constitutional rights." 48 Finally, the CCJ granted the Mayan communities non-pecuniary damages to be quantified in a BZ $\$ 300.000$.00 fund as a first step toward compliance with the Belizean Government's duty to protect Maya customary land tenure. ${ }^{49}$

\section{B. The CCJ's Fundamental Rights Turn on the Court's Original Jurisdiction}

The CCJ has also gotten involved with politically sensitive issues in its OJ, where, in principle, the Court is bound to interpret and apply the RTC and secondary Community Law. In the period 2005-2011, this jurisdiction was mainly used by large companies for common market related matters. ${ }^{50}$ From 2012, however, a different set of cases concerning freedom of movement of CARICOM nationals reached the Court.

The first — and perhaps most important—among these was brought by a Jamaican woman, Shanique Myrie, against the State of Barbados. Myrie alleged that the behavior of the Barbadian border officers at the Bridgetown Airport - who had mistreated her and denied her access to Barbadosconstituted a violation of her human and fundamental rights; her right to freedom of movement within the CARICOM; and her right to nondiscrimination on the ground of nationality granted to CARICOM nationals by the RTC. ${ }^{51}$

This decision is also revelatory of the CCJ's willingness to get involved with politically sensitive cases. Although the Court formally rejected the human rights claim brought forward by Myrie stating that the Court is only competent to interpret and apply the RTC and secondary laws emanating from the Treaty, ${ }^{52}$ the judges ruled in favor of Myrie, ordering Barbados to pay compensatory damages for the violation of her rights under the RTC. Myrie had also important systemic effects, as it emboldened the protection of fundamental rights in the CARICOM. In this decision, the CCJ deepened the outreach of the doctrine of "correlative rights," which the Court had established in one of its previous decisions. According to this doctrine, although formally the RTC does not give rights to individuals and only establishes obligations on the Member States, these obligations are mirrored by "correlative rights" when their non-fulfillment damages the interests of individuals. ${ }^{53}$ Following Myrie, these "correlative rights" can now be

\footnotetext{
48. Id. at 47 .

49. Id. at 78 .

50. Caserta \& Madsen, supra note 14.

51. Myrie, supra note 7, at 2-4.

52. Id. at 6 .

53. According to this doctrine, in the CARICOM, rights are not expressly given by the RTC but
} 
activated at the Community level by private litigants bringing cases directly before the CCJ, without the exhaustion of local remedies and without the need of filing cases before national judges.

Myrie was soon followed by two other disputes dealing with free movement in the CARICOM. In these cases, Maurice Tomlinson, a Jamaican LGBTI rights activist, asked the CCJ to declare the provisions of the Immigration Acts of both Belize and Trinidad and Tobago banning the entrance of homosexuals into these two countries in violation of his right to free movement within the CARICOM.

The two Tomlinson cases were viewed by many as risking a backlash against the Court because they potentially incited a conflict between international human rights and local cultural sensitivities. ${ }^{54}$ It may also be for this reason that the CCJ formally dismissed the two cases, ruling that the practices of Belize and Trinidad and Tobago in relation to their Immigration Acts were not incompatible with the CARICOM Law. ${ }^{55}$

Despite formally rejecting the case, in the judgment, the Court introduced important principles that enhance the protection of fundamental rights in the CARICOM through obiter dicta. Most notably, that: $i$ ) CARICOM Law makes the admission of homosexual nationals from other CARICOM States a legal requirement, notwithstanding contradictory positions of national Immigration Acts; and ii) that the dismissal of Tomlinson's claims should not allow Belize and Trinidad and Tobago to indefinitely retain laws seemingly in conflict with Community Law obligations, as Member States are obliged to ensure that national laws, subsidiary legislation and administrative practices conform to CARICOM Law. $^{56}$

C. Litigating in the Shadow of the International Court of Justice: the $\mathrm{CACJ}$ as an Inter-State Court

Similar to the CCJ, the CACJ did not refrain from getting involved with politically sensitive issues either. Two of these cases involved Nicaragua and Honduras and the ratification of the Lopez-Ramirez Treaty between Colombia and Honduras, through which several islands, marine areas, and

are rather extracted from obligations that the Treaty places on Member States. See TCL v. Guyana, [2009] CCJ 1 (OJ). See also Salvatore Caserta \& Mikael Rask Madsen, Consolidating Supranational Authority: the Caribbean Court of Justice Decisions in the Tomlinson Cases, 110 AM. J. INT'L L. 533, 533 (2016). See generally DAVID BERRY, CARIBBEAN INTEGRATION LAW (2014).

54. Caserta \& Madsen, supra note 14.

55. According to the Court, in fact, both Belize and Trinidad and Tobago have repeatedly admitted homosexuals - even the claimant, Mr. Tomlinson - in more than one instance. Maurice Tomlinson v. the State of Belize and the State of Trinidad and Tobago, [2016] CCJ 1 (OJ), at [24].

56. Caserta \& Madsen, supra note 5. 
submarine areas were transferred from Nicaragua and Jamaica to Honduras and Colombia. ${ }^{57}$ As a reaction to the ratification of such Treaty, Nicaragua imposed additional taxes over the goods coming from Honduras and even suspended commercial relations with the latter. Shortly after, the two States moved troops to their respective borders, getting ready for military action. Honduras even declared a state of alert. ${ }^{58}$ Following these occurrences, in 1999, Nicaragua and Honduras each filed a case before the CACJ: Nicaragua to ascertain the nullity of the ratification of the Lopez-Ramirez Treaty; Honduras to invalidate the Nicaraguan economic countermeasures as these allegedly violated SICA law.

In its rulings, the CACJ revealed its proclivity for getting involved with politically sensitive issues. The first hint in this regard is provided by the fact that, even though the CACJ has formally no compulsory jurisdiction over territorial disputes ${ }^{59}$ the judges accepted the cases claiming that the Court's role is not limited to deciding technical issues related to regional economic integration, but also to: i) transform the Central American isthmus into a unified and pacific nation; ${ }^{60}$ ii) "reaffirm and consolidate Central American self-determination;" $" 61$ and, iii) promote, in a harmonic way, the economic, social, cultural, and political development of the Member States and of the region. ${ }^{62}$ Furthermore, in deciding the merits of the cases, the Court did not hesitate in ruling against the two States. The CACJ, in fact, declared: i) that the Lopez-Ramirez Treaty infringed the principles and obligations of the Protocol and that Honduras was directly responsible for the violations; ${ }^{63}$ and

57. CACJ 25-05-29-11-1999 and 26-06-03-12-1999. The dispute had originated already in 1858 and lasted until the 1960s, when the diplomatic mediation of the Organization of American States persuaded the two states to submit the dispute to the ICJ, which eventually decided in favor of Honduras. In 1986, however, the drafting of the Lopez-Ramirez Treaty between Honduras and Colombia had resurrected the conflict, pushing Nicaragua to file another case before the ICJ. Yet, as the actual ratification of the Treaty was delayed, the controversy remained suspended until 1999, when - overnight - the legislature of Honduras proceeded to the ratification of the Treaty.

58. Both Nicaragua \& Honduras Claim Victory After Regional Court Rules on Boundary-Tariff Issues, NOTICEN: CENT. AM. \& CARIBBEAN AFFAIRS (Dec. 6, 2001), http://www.thefreelibrary.com/REGION\%3A+BOTH+NICARAGUA+\%26+HONDURAS+CLAIM+ VICTORY+AFTER+REGIONAL+COURT. . .-a080643478.

59. See Costa Rica-El Salvador-Guatemala-Honduras-Nicaragua-Panama: Statute of the Central American Court of Justice, 34 I.L.M. 921, 930 (1995) (establishing that the Court has no jurisdiction over territorial disputes between Member States, unless the two States formally agreed to submit the dispute to the CACJ).

60. CACJ 25-05-29-11-1999, supra note 57, at considerando IX.

61. Tegucigalpa Protocol to the Charter of the Organization of Central American States (ODECA) art. 4 (g), Dec. 13, 1991, 1695 U.N.T.S. 400.

62. See id. at art. $3(\mathrm{~h})$.

63. CACJ 25-05-29-11-1999, supra note 57, at resuelve I). See also the dissenting opinions of Justice Adolfo Leon Gomez and of Justice Eduardo Gauggel Rivas. 
ii) that by imposing additional taxes over the goods coming from Honduras and by suspending commercial relations with the latter, Nicaragua had violated SICA law. ${ }^{64}$

These two rulings are not exceptional, and they constituted the first step toward transforming the CACJ from a mere regional economic court into the ultimate Central American arbiter of inter-state disputes. In 2011, the Court was called to preside over another highly sensitive and long-standing territorial dispute involving Costa Rica and Nicaragua. ${ }^{65}$ In this case, two Nicaraguan NGOs asked the CACJ to stop Costa Rica from constructing a highway in the environmentally protected area of the Rio San Juan. The case assumed even more political connotations because, since the Court's establishment, Costa Rica had repeatedly refused to submit to its jurisdiction for reasons connected to the CACJ's broad competences. In this decision, the CACJ proved itself not only not to be averse to politically sensitive issues, but also that these types of cases are a central aspect of its competences. First, despite the vehement protests of the Costa Rican Government, the CACJ declared its jurisdiction to hear the case. ${ }^{66}$ Second, again ignoring the Costa Rican Government's blistering remarks, the CACJ did not hesitate in condemning the State for damaging the environment and for having violated several international and regional treaties.

\section{Democratization through Judicial Means: the CACJ as a Regional Constitutional Court}

The willingness of the CACJ to deal with politically sensitive issues is perhaps best illustrated by the fact that, in the early 2000s, the Court was called to solve a high profile dispute between two former Nicaraguan Presidents, both members of the Liberal Party, Enrique Bolaños, and his predecessor, Arnoldo Alemán. ${ }^{67}$ The conflict initiated as early as 2002 , when the newly elected Bolaños led an anti-corruption campaign, which caused the imprisonment of Alemán. In an attempt to escape the conviction, Alemán

64. CACJ 26-06-03-12-1999, supra note 57, at resuelve I) and II).

65. CACJ 12-06-12-2011. The tension between the two states peaked in 2010, when Nicaragua began to build an inter-oceanic channel in the area of the Rio San Juan. In response, Costa Rica sent police officers to its borders, as did Nicaragua. Costa Rica then filed a case at the ICJ alleging that the Nicaraguan military activities in the area constituted a breach of treaty obligations toward Costa Rica. In 2011, the ICJ provisionally ruled that both Costa Rica and Nicaragua must refrain from sending or maintaining security forces in the area and that the Nicaraguan dredging was allowed, as it had been conducted on Nicaraguan territory. See Press Release, International Court of Justice Press Release No. 2010/38, Costa Rica institutes proceedings against Nicaragua and requests the Court to indicate provisional measures (Nov. 19, 2010); See Certain Activities Carried Out by Nicaragua in the Border Area (Costa Rica v. Nicaragua), Provisional Measures, Order of 8 March 2011, I.C.J. Rep. 2011, p. 6.

66. Costa Rica-El Salvador-Guatemala-Honduras-Nicaragua-Panama, supra note 59, at 932.

67. CACJ 69-01-03-01-2005, supra note 10. 
filed a case before the CACJ claiming his immunity as a member of the Central American Parliament (PARLACEN). The CACJ, however, rejected the case, ruling that the suspension of the national immunity decided by the Nicaraguan Parliament had also caused the decay of Alemán's regional immunity.

Having lost the first legal battle before the CACJ, Alemán attempted to politically isolate Bolaños by means of an agreement (El Pacto) with the leftist Sandinista Party. In short, the part of the Liberal Party allied with Alemán and the Sandinistas coalesced with the goal of passing constitutional reforms aimed at disempowering and eventually impeaching Bolaños, securing for themselves the control of key political institutions, and, ultimately, gaining amnesty for Alemán. Soon after El Pacto, the National Assembly of Nicaragua passed a bill revoking the President's power to directly appoint key governmental figures. In response, President Bolaños filed a motion before the Nicaraguan Supreme Court. This case was, however, rejected by the Nicaraguan highest judicial organ, which even declared the section $\mathrm{f}$ ) of Article 22 of the Statute of the CACJ unconstitutional and inapplicable. ${ }^{68}$ Finally, President Bolaños, in a desperate attempt to cling to his chair, invoked the contested Article 22 and dragged the Nicaraguan Parliament before the CACJ, asking the regional court to declare the invalidity of the constitutional reforms. ${ }^{69}$

This case put an immense amount of strain on the CACJ, especially on the two Nicaraguan judges, who were called to take a stance either against their own Supreme Court or against their own President. Additionally, being that the seat of the Court was located in Nicaragua, the Court ended up in the midst of the Nicaraguan political debate and, during the proceedings, people gathered in front of the Court's Headquarters to voice their discontent with the judges' involvement in the dispute. ${ }^{70}$ The situation was so charged that one person close to the Court revealed that one of the two Nicaraguan judges avoided getting too involved with the proceedings in order to avoid criticisms and even retaliations against him. ${ }^{71}$ The CACJ, however, kept the pressure at bay. First, the Court admitted the case and even released a preliminary measure, asking the Nicaraguan Parliament to suspend the reforms while its decision was pending. Second, the Court declared the

68. Sentencia [S.] No. 15, 29 March 2005, Sala Constitucional, [Supreme Court of Justice] p. 47, Cons. I (Nicar.). Article 22(f) of the Statute empowers the CACJ to rule over separation of powers disputes between the constitutional organs of the Member States.

69. Interview n.6.

70. Interview n.5.

71. Interview n.7, n.8. 
reforms initiated by the Legislative Assembly of Nicaragua in violation both of the Nicaraguan Constitution and of several treaties of the SICA. ${ }^{72}$

\section{IMPLICATIONS OF THE EXPERIENCE OF THE CACJ AND OF THE CCJ FOR THE THEORIES OF DELEGATION TO ICS}

This section analyzes how the experiences of the CACJ and of the CCJ relate to the theories of delegation discussed in section II, namely, P-A Theory, Trustee Theories, and the Altered Politics Framework.

As to the P-A Theory, the experiences of the CACJ and of the CCJ contradict many of its main assumptions. The two Courts did not act consistently with the wishes of their principals. Although the founders of the Courts initially provided them with far-reaching powers, once these were up and running, both their Member States and key Central American and Caribbean legal and political elites repeatedly - and rather explicitlythreatened to withdraw their support if the two Courts got too involved with politically sensitive issues. Hence, by presiding over claims involving human and fundamental rights (the CCJ) and inter-state and separation of powers within the constitutional organs of the Member States issues (the CACJ), both Courts defied the interests of their principals. More specifically, the rulings presented above placed the CACJ and the CCJ at odds with the interests of many of their Member States, according to which both the SICA and the CARICOM are mere fora for handling diplomatic and trade matters, and not supranational legal communities aimed at protecting and enforcing the rule of law and democratic governance. The experiences of the CACJ and of the CCJ also contradict P-A Theory because, although the two Courts have often gone against the interests of their Member States, these have not punished them for overstepping their authority. As to the CCJ, although discontent with the outcome of Myrie, Barbados complied with the decision without challenging the authority and legitimacy of the Court. Moreover, regardless of the Court's highly political and controversial judgments in Pratt and Morgan and The Maya cases, the authority of the CCJ in its Appellate Jurisdiction has increased and several undecided states even took significant steps to fully ratify such jurisdiction. ${ }^{73}$ As to the CACJ, the Member States of the SICA have attempted to curtail the Court's competencies, in 1997, with the Declaration of Panama II, again, in 1998,

72. See CACJ 69-01-03-01-2005, supra note 10, at 25-26.

73. Dominica accessed the Appellate Jurisdiction in 2015, while several East Caribbean countries began consultations in relation to their accession to the Court. See Media Release, Caribbean Court of Justice, CCJ President Travels to Antigua for Initial Consultations (Aug. 20, 2015), http://www.caribbeancourtofjustice.org/news/ccj-president-travels-to-antigua-for-initial-consultations. On the authority of the CCJ, see generally Caserta \& Madsen, supra note 14. 
with the Declaration of Managua, and, finally, in 2003-2004, in two Presidential Meetings held in Belize and Guatemala. These attempts, however, remained un-executed for lack of political consensus at both the national and regional level, thus leaving the competencies of the CACJ intact. $^{74}$

The Trustee Theories, conversely, provide valuable insights for explaining the experiences of the CACJ and of the CCJ. The Central American and Caribbean judges did not behave as mere agents of their delegating authorities, but as independent professionals attempting to bring their own legitimacy and authority to the two Courts. Moreover, the judges not only produced bold rulings on very sensitive topics, but they also justified their claims on legal grounds by relying on their "superior" expertise and knowledge of the relevant treaties. Trustee Theories are finally corroborated by the fact that the two Courts embarked in ambitious readings of their treaties to make themselves palatable to broader pools of "compliance partners," 75 making them the beneficiaries of their jurisprudence, as I will discuss in detail in Section V of the paper.

Other assumptions of Trustee Theories, however, do not entirely fit the Central American and Caribbean experiences. Trustee Theories claim that ICs become effective when they enjoy the institutional support of the other organs of their communities, such as the Heads of Government and Commissions and/or Regional Secretariats. ${ }^{76}$ This is not the case in Central America or in the Caribbean, where both Courts were (and are) not supported by other institutional actors in developing their case-law. ${ }^{77}$ Moreover, according to Trustee Theories, ICs are more likely to produce ambitious rulings when significant disputes of non-compliance with treaty law are regularly brought to their attention. ${ }^{78}$ This does not occur in Central America or in the Caribbean, where non-compliance disputes with treaty law are preferably solved through diplomatic and political channels rather than through adjudication. ${ }^{79}$

The CACJ and the CCJ also defy some of the assumptions of the Constrained Independent Theory, especially regarding the part of the

74. MetCAlF \& PAPAgEORgiou, supra note 4, at 97-103.

75. Compliance partners are domestic and transnational actors who "either orchestrate compliance or construct counter-pressures that alter the political balance in favor of policies that better cohere with international legal obligations." ALTER, supra note 21, at 20.

76. See generally JONAS TALLBERG, MAKING STATES COMPLY: THE EUROPEAN COMMISSION, THE EUROPEAN COURT OF JUSTICE \& THE ENFORCEMENT OF THE INTERNAL MARKET (1999).

77. See generally Caserta, supra note 3 .

78. Sweet \& Brunell, supra note 26, at 62-63.

79. See O'Brien \& Foadi, supra note 4, at 346-47; see generally OTILIO MIRANDA, DERECHO DE LA COMUNIDAD CENTROAMERICANA (2013). 
approach that claims that states establish independent ICs to promote the credibility of their commitments. ${ }^{80}$ The Central American and Caribbean States established the two Courts chiefly to enforce trade liberalization and to limit the widespread disregard of SICA and CARICOM laws and policies. Yet, both Courts have largely failed at enforcing market integration commitments both in terms of number of cases decided and in terms of the impact of their Community Law jurisprudence on the realities of Central American and Caribbean integration. ${ }^{81}$

The Altered Politics Framework also provides valuable insights for explaining the experiences of the CACJ and the CCJ. In line with this model, both Courts have taken into consideration the interest of not only the Governments of their Member States, but also those of broader sets of "compliance constituencies" when deciding their cases. One key assumption of the Altered Politics Framework, however, is not present in Central America and the Caribbean. International law, human and fundamental rights, as well as democratization and pacification issues do not necessarily enjoy the political support of those actors who are in power in the national and regional political arenas, such as the SICA and CARICOM Heads of Government and the national judges. Right before the beginning of the CCJ's operations, the heated conflict between the JCPC and many Caribbean countries on death penalty issues resulted in widespread skepticism regarding international law and human rights throughout the whole region. ${ }^{82}$ While the passing of time has softened the Caribbean turmoil on such topics, a general lack of support for these instruments remains. Similarly, the enthusiasm toward democratization and pacification that permeated the Central American region during the late 1980s and early 1990s soon softened, and, still today, the countries of the isthmus are struggling to complete their transition to democracy. ${ }^{83}$ Hence, the claim that the CACJ and the CCJ assist governments and other national actors in adopting policies that may be domestically controversial but consistent with international law does not find full empirical confirmation. ${ }^{84}$

In addition to these theory-specific assessments, other more general considerations can be brought forward to corroborate the point already expressed in this section. Delegation theories cannot entirely account for the

80. See generally Helfer \& Slaughter, supra note 20.

81. Interview n.9. See also Caserta, supra note 3.

82. See Helfer, supra note 37.

83. See, e.g., Ellen Moodie, El Salvador in the Aftermath of Peace: Crime, Uncertainty AND the Transition to Democracy (2010); CENTRAL AMERICA IN THE NeW MillenNiUm: Living TrANSITION AND REIMAGINING DEMOCRACY (Jennifer L. Burrell \& Ellen Moodie eds., 2013).

84. See generally ALTER, supra note 21. 
behavior of both the CACJ and of the CCJ because their analysis chiefly focuses on the political dynamics related to the formal act of empowerment. In turn, this means that these theories can only account for why states create ICs at a specific point in time and that they do not (and cannot) address broader issues related to the process of institutionalization of ICs or to what direction ICs may take once established.

The Theories of delegation also seem to imply that delegating states are the only relevant actors whose interests must be unveiled if one wants to understand the creation as well as the reasons of the behavior of an IC. ${ }^{85}$ Yet, the fact that both the CACJ and the CCJ challenged the interests of their Member States, and that these States have not reacted negatively in response, reveal that the question of compliance or non-compliance with an IC's decision is more complex than what these Theories tend to suggest and that it involves a multitude of actors and interests beyond states. In this regard, Trustee Theories and the Altered Politics Framework are more suited to explain the CACJ and the CCJ as they expand the analysis to a broader pool of actors. Yet, even these two theories are not entirely satisfactory as they, ultimately, rely on pre-defined and rationalist constructions of the interests of the agents interacting with ICs. Both Trustee Theories and the Altered Politics Framework frame ICs in terms of welfare-improving solutions to problems of incomplete information and high-transaction costs between states and other rational actors. Yet, as it will be shown in the following section of the paper, the interests of individual actors and groups hardly follow pre-defined trajectories. Interests are, in fact, socially constructed and, either directly or indirectly, influenced by social rules, cultural contents, visions of the world, ideas of legality and other similar factors. ${ }^{86}$

In sum, although some of the above discussed theories provide useful insights for understanding the CACJ and of the CCJ, each theory alone cannot fully account for the two Courts' involvement with politically sensitive issues.

85. In this discussion, it is worth adding that, recent scholarship has pointed out that States are not monolithic institutions with uniform and singularly identifiable interests as these theories seem to assume. On the contrary, States are disaggregated in many independent flows of power characterized by technical skills, each with their own specific interest to protect and fulfill. See, e.g., ANNE-MARIE SLAUGHTER, A NEW WORLD ORDER 12 (2009).

86. This is in line with constructivist and sociological approaches to international organizations and courts. See, e.g., Michael N. BARnett \& MARTha FinNEMORE, Rules for the World: International Organizations in Global Politics 2 (2004); Neil Fligstein, Markets as Politics: A Political-Cultural Approach to Market Institutions, 61 AMERICAN SoC. REV. 656, 660 (1996); Antoine Vauchez, The Force of a Weak Field: Law and Lawyers in the Government of the European Union (For a Renewed Research Agenda), 2 INT. POL. Soc. 128, 131 (2008); Madsen \& Dezalay, supra note 13. 


\section{BRINGING THE SOCIAL BACK IN: EXPLAINING THE INVOLVEMENT OF THE CACJ AND OF THE CCJ WITH POLITICALLY SENSITIVE DISPUTES}

If the theories discussed above cannot fully grasp the reasons why the CACJ and CCJ have gotten involved with politically sensitive issues, how can we theoretically make sense of the behavior of these two Courts?

Transnational Field Theory and Reflexive Sociology provide the theoretical and methodological tools to answer this puzzle. These theories approach ICs - and more generally (legal) institutions - not in terms of autonomous entities that develop and change through endogenous and selfreferential logics, but rather as social constructions deeply embedded in differentiated fields of power, which shape their activities through a variety of processes (i.e., professional interests, visions of law, ideologies, education, socialization, and so on). ${ }^{87}$

The focus of the analysis, hence, shifts from a trans-governmentalist line of thinking - according to which international institutions are the spinoff of rationally constructed interests of transnational constellations of agentsto a more sociologically grounded vision that constructs ICs in terms of institutional crystallizations of diverging and competing national modes of production, professional interests, and visions of law. ${ }^{88}$ In other words, Transnational Field Theory and Reflexive Sociology, by allowing an examination of the interplay between the agency of ICs and the transformation of the social structures in which they act and evolve, shed light on the making of these institutions, pinpointing to how larger societal and geopolitical forces impact the evolution of ICs and of their behavior. ${ }^{89}$

In this regard, the Bourdieusian notion of the field ${ }^{90}$ is an especially pertinent research tool. The field, in fact: "populates these institutions [ICs] with competing actors and tracks their socialization, personal trajectories, and professional careers," thus allowing to trace: "the socio-genesis of transnational institutions and groups as well as the power relations in which they are embedded." 91

87. See Vauchez, supra note 86. See also Madsen \& Dezalay, supra note 13.

88. Similar in this regard, to what was claimed by the sociology of organizations. See generally, e.g., Paul J. Di Maggio \& Walter W. Powell, The Iron Cage Revisited: Institutional Isomorphsim and Collective Rationality in Organizational Fields, 48 AM. Soc. REV. 147, 150 (1983); Richard W. ScOTT, ET AL., INSTITUTIONAL ENVIRONMENTS AND ORGANIZATIONS 20 (1994).

89. Madsen, supra note 13, at 448-49.

90. Social fields are "spaces of contestation over defining the law in which different agents occupy positions relative to the portfolio of capitals they can muster and which are 'capitalized' according to the logic of the specific field in question." Id. at 400.

91. Vauchez, supra note 86. 
In what follows, it will become clear that power relations, professional practices, interests, visions of the world, and the national positioning of the Central American and Caribbean legal and political elites in their respective legal fields have played a fundamental role in shaping both the institutional outlook and - most importantly - the practices of the CACJ and of the CCJ, pushing them to go beyond their roles as regional economic courts and to explore the full extension of their powers.

The paper does not provide a full-fledged analysis of the Central American and Caribbean legal fields. I rather use the logic of the field to highlight two different-yet inherently correlated-aspects, which are of pivotal importance for understanding the involvement of the two Courts with politically sensitive issues: $i$ ) the trans-historical trajectories of the main structuring forces of the Central American and Caribbean legal fields; and ii) the professional paths of the judges eventually chosen to sit on the benches of the two Courts, which are strongly linked to these structural dynamics.

\section{A. The Protracted Geneses of the CACJ and the CCJ}

In the two following sub-sections, I provide a socio-genesis of the two ICs object of enquiry, showing that the need of establishing two regional economic Courts to support the implementation of the policies of the SICA and the CARICOM was only the most recent development characterizing the Central American and Caribbean legal fields. Conversely, the process of creation of the two Courts was significantly shaped by other-very different-structural forces that have characterized the Central American and Caribbean legal fields over time. These forces are: decolonization from the United Kingdom in the Caribbean, and pacification through legal and judicial means in Central America.

Ultimately, this shows that both Courts are not only mere byproducts of the increased legalization of international relations that followed the end of the Cold War, ${ }^{92}$ but that this legalization layered on top of several other forms of legality, interests, normative ideas, and social practices that have characterized the Central American and Caribbean legal fields over time.

1. The Creation of the CCJ at the Crossroads of Decolonization and Regional Integration

The CCJ is the institutional crystallization of two divergent movements of the Caribbean legal field. ${ }^{93}$ The first is the one correctly captured by the main narrative related to the CCJ, according to which the Court is an EU-

92. See Legalization AND World Politics 17 (Judith L. Goldstein, et al. eds., 2001); Alter, supra note 21.

93. Caserta \& Madsen, supra note 14 , at 90. 
style regional economic court ${ }^{94}$ aimed at reviving the CARICOM, which, up to that point, had been highly dysfunctional and ineffective at securing compliance of the Member States with its policies. ${ }^{95}$

Once the Court is approached from a more trans-historical and actorbased perspective, however, it becomes apparent that, above and beyond being the judicial institution of the CARICOM, the present CCJ constitutes the last of several failed attempts at replacing the JCPC as the apex court of the former English West Indian colonies.

The first proposal of a Caribbean Court of Appeal was first advanced in 1901, when a Jamaican newspaper suggested to replace the system of colonial justice with a West Indian Court of Appeal. ${ }^{96}$ Similar proposals were advanced in 1932 at the Conference of Roseau and in 1947 at the Montego Bay Conference. An actual Caribbean Court of Appeal was eventually established to replace the JCPC as part of the Federation of the West Indies in 1958. Yet, as the Federation crashed in 1962 and the Caribbean States achieved their independence singularly, many of them opted for maintaining the JCPC as their court of last resort. The discussions related to the creation of a local court to replace the JCPC, however, continued intermittently until the 1990s, when the Caribbean legal professions entered into a heated conflict with the JCPC on issues related to the constitutionality of mandatory death penalty for murder granted by many constitutions of the States of the region. Thereafter - in conjunction with the need of vesting the CARICOM with a Community Court to respond to the challenges posed by the end of the Cold War - the present CCJ was established as both an appellate and an international court. ${ }^{97}$

This double movement characterizing the long period of gestation of the Court significantly shaped the constellation of the Caribbean legal field. In the shadow of these two structural forces, a professional and power struggle between two social groupings of lawyers, each with very different ideas related to Caribbean Community Law, took place. Initially, the field was dominated by a relatively small but powerful group of English-educated Caribbean lawyers. Central figures of this social constellation of legal

94. See, e.g., Derek O'Brien \& Sonia Morano-Foadi, The Caribbean Court of Justice and Legal Integration within CARICOM: Some Lessons from the European Community, 8 L. \& PRAC. INT'L CTS. \& TRIBS. 399, 400 (2009).

95. See, e.g., THE WeSt INDIAN COMM'N, TIME FOR ACTION: REPORT OF THE WeSt INDIAN COMMISSION (1992); O’Brien \& Foadi, supra note 4, at 347.

96. The Judicial Committee of the Privy Council, The Daily Gleaner, Mar. 6, 1901, http://www.caribbeancourtofjustice.org/about-the-ccj/ccj-concept-to-reality.

97. For a more detailed history of these developments, see SPENCER MAWBY, ORDERING INDEPENDENCE: THE END OF EMPIRE IN THE ANGLOPHONE CARIBBEAN (1947-1969) 150 (2012). See also, Caserta \& Madsen, supra note 14, at 90. 
professionals were, among others: Karl Hudson Phillips, ${ }^{98}$ Ramesh Lawrence Maharaj, ${ }^{99}$ Fenton Ramsahoye, ${ }^{100}$ as well as Michael de la Bastide and Sir Dennis Byron, who would later become Presidents of the CCJ. ${ }^{101}$

Because of the absence of a Faculty of Law in the region, ${ }^{102}$ these individuals obtained their legal education in the United Kingdom. During this English passage, these lawyers developed specific sensitivities related to Caribbean Community Law both as an extension of (English) human and fundamental rights and as a (hypothetical) tool for completing the circle of Caribbean independence from its metropolitan power. Eventually, when these lawyers returned to the Caribbean, they ended up monopolizing the legal job market practicing law transnationally in all jurisdictions of the Caribbean and before the JCPC. ${ }^{103}$

The strong connection to the colonial metropolis developed by this old generation of Caribbean lawyers instilled in them, and in many other Caribbean lawyers, a strong skepticism related to any kind of local legal knowledge. Importantly, for a long time, the old lawyers were suspicious in relation to the project of a Caribbean Court, as they feared that replacing the JCPC with a local judicial institution would curtail human and fundamental rights standards in the region. At the same time, the creation of a local court

98. Mr. Hudson Phillips graduated in law at the University of Cambridge in 1956 and called at the bar at Gray's Inn, London. He served as member of the Parliament of Trinidad and Tobago from 1966 to 1976. From 1969 to 1973, he was appointed as Attorney General and Minister of Legal Affairs of Trinidad and Tobago. He made a name for himself as a trans-Caribbean lawyer as he practiced law in several jurisdictions. He participated in the murder trial of the Grenadian Prime Minister - Mr. Maurice Bishop - as well as in many high-profile cases throughout the Caribbean. In 1999 he was also appointed as President of the Law Association of Trinidad and Tobago. In 2003, he was appointed as the first judge of the International Criminal Court.

99. Mr. Maharaj graduated in law in London in 1969 and called at the bar at Inner Temple. He was admitted to practice in several Caribbean countries, such as Trinidad and Tobago, St. Vincent and the Grenadines, and Grenada. He was a member of the Trinidadian Parliament in more than one legislature and he served as Attorney General and Minister of Legal Affairs of Trinidad and Tobago from 2000.

100. Mr. Ramsahoye graduated in law at the London University in 1953, called to bar at Lincoln's Inn in 1953, awarded a PhD in Comparative Land Law from the London School of Economics and Political Sciences in 1959. He is licensed under the bars in Guyana, Trinidad and Tobago, Barbados, Jamaica, and the Territories of the Eastern Caribbean included Montserrat, and the British Virgin Islands. He holds the record for making the most appearances before the JCPC in the Caribbean. Additionally, he has been member of the Guyanese Parliament from 1961 to 1973 and Attorney General of Guyana from 1961 to 1964.

101. I will discuss the professional profiles of both Mr. de la Bastide and Sir Byron in the following sub-section of the paper.

102. The first local Faculty of Law was established only in 1970 in Barbados. The Faculty of Law, About Us, THE UNIVERSITY OF THE WEST INDIES, https://www.cavehill.uwi.edu/Law/about-us.aspx (last visited Oct.24, 2017). This was soon followed by other Caribbean Faculties of Law certified to issue legal diplomas in Jamaica (1973), Trinidad \& Tobago (1973) and Bahamas (1998). Legal studies are now also available in Guyana, http://uog.edu.gy/faculties/fss/department-of-law.

103. Caserta \& Madsen, supra note 14, at 93-96. 
contested their professional privileges and power, as this directly challenged the hegemony of the English Common Law as the law of the land of the Caribbean States. ${ }^{104}$

By the 1970s, however, the old lawyers' unique position of power in the field began to be challenged by a newer generation of Caribbeaneducated lawyers. ${ }^{105}$ A key role in this development was played by the opening of the Faculty of Law of the University of West Indies (UWI) in Barbados in 1970, which, over time, nurtured a generation of Caribbean lawyers less skeptical towards the idea of replacing the appeals to the JCPC with a local Court of Appeal and supportive of the idea of strengthening the integration project by, among other things, equipping the CARICOM with an international judicial institution. ${ }^{106}$ These two competing professional and ideological views related to Caribbean Community Law remained in conflict until the early 2000s, when, as a result of the new JCPC human rights jurisprudence on capital punishment, both the young and the old Caribbean lawyers coalesced to establish the present CCJ with both Appellate and Original Jurisdictions.

This diachronic and actor-based socio-genesis of the CCJ provides important evidence for explaining the Court's involvement in politically sensitive issues. From this history, it emerges that the present CCJ is not only a recent byproduct of the legalization process triggered by the end of the Cold War, but also an institutional crystallization of continuous and overlapping dialectics between the different levels of structures and discourses of power at play in the emerging field of Caribbean law over the course of history.

This is not mere historical curiosity, as the equilibrium of power of the field surrounding the CCJ remains rather fragile even today. The power battle between the older and the younger lawyers over the definition of Caribbean Community Law is still ongoing. This can be seen, for example, in that the widespread support enjoyed by the CCJ at the end of the 1990s, which stemmed from the outrage against the death penalty rulings of the JCPC, had already vanished when the Court began its operations in 2005. At this point, a new set of critics backed up by the English-educated elites began

104. According to one interviewee, several law firms in Trinidad specialize in cases before the Privy Council. They have generally been opposed to the CCJ for fear of losing clients. Interview n. 3 .

105. 1970 is the year in which the first truly Caribbean Faculty of Law was established in the context of the University of the West Indies. See, The Faculty of Law, About Us, THE UNIVERSITY OF THE WEST INDIES, https://www.cavehill.uwi.edu/Law/about-us.aspx (last visited Oct. 24, 2017).

106. See Caserta \& Madsen, supra note 14, at 95-96. 
to label the newly established tribunal a "hanging court," a court specifically set up to continue the use of capital punishment in the Caribbean. ${ }^{107}$

It is, thus, not by chance that one of the first, and perhaps most important, cases decided by the present CCJ concerned precisely death penalty issues and the CCJ's relationship with the JCPC. Likewise, it is not accidental that the Court is transforming its international jurisdiction from a venue for trade dispute into one dedicated to regional enforcement of human and fundamental rights, thus showing to its constituencies to be a Court able to handle the Caribbean system of justice.

In conclusion, all of the above shows that the idea of establishing a regional court to deal with the technicalities of Caribbean economic integration was only a relatively recent occurrence that layered on top of a long-lasting discourse of politically sensitive ideas and power, mostly centered on decolonization, as well as human and fundamental rights. For more than a century, the main structuring forces of the Caribbean legal field - and, accordingly, the main professional interests and visions of law of the legal and political elites within that field-revolved not so much around the idea of economically and legally integrating the region, but rather around the more politically contested production of a local jurisprudence on human and fundamental rights able to end the post-colonial legal and political dependence of the Caribbean from the JCPC and the United Kingdom. This, in my view, contributes to explaining the CCJ's predisposition — or at least the missing reluctance - towards getting involved with politically sensitive issues.

2. The Creation of the CACJ at the Crossroads of Pacification and Regional Integration

Similar to the CCJ, the CACJ is likewise not a mere byproduct of the legalization of Central American economic integration triggered by the end of the Cold War, but the institutional crystallization of the different movements that characterized the Central American social and legal fields over time. Also in the case of the CACJ, the first of these movements has been highlighted by the scholarship on the CACJ, according to which the Court is an EU-style regional economic court aimed at enforcing the policies of the SICA. ${ }^{108}$ However, once the Court is approached from a transhistorical and actor-based perspective, it becomes clear that the need to establish a regional economic court in Central American is a relatively recent

107. See, e.g., Leonard Birdsong, The Formation of the Caribbean Court of Justice: The Sunset of British Colonial Rule in the English Speaking Caribbean, 36 U. MiAMI INTER-AM. L. Rev. 197, 203 (2005).

108. See, e.g., MEtCAlF \& PAPAgEORgiou, supra note 4, at 19-20. 
development, and that the CACJ is also - if not above all — the last attempt at creating an IC to pacify and democratize Central America by legal and judicial means. ${ }^{109}$

The argument is even more compelling than in the case of the CCJ, because several international judicial institutions aimed at pacifying the Central American region actually existed before the present CACJ. The most important of these attempts was made in 1907, when the Cartago Court- the first IC in world history - was established with the task of "maintaining peace and harmony inalterably [...] without being obliged to resort in any case to the employment of force," 110 and, ultimately, of representing the "national conscience of Central America." "While the Cartago Court was short lived, ${ }^{112}$ the idea of pacifying Central America by means of an international judicial institution persisted up until the early 1990s, when, in conjunction with the peace negotiations of Esquipulas $I$ and $I I$ and the reformation of the system of Central American regional economic integration, the present CACJ was established. ${ }^{113}$

This double movement characterizing the Central American legal field holds key explanatory value for understanding the CACJ's involvement in politically sensitive issues. The two structuring forces of the field significantly influenced the general constellation of the Central American

109. The first proposals for a regional court were advanced in the early $20^{\text {th }}$ Century, when the States of the region - under the auspices of the United States - created several arbitral tribunals and courts in an effort to soften their political and territorial controversies. THOMAS L. KARNES, THE FAILURE OF UNION: CENTRAL AMERICA 1824-1975 (1976).

110. Preamble of the Convention.

111. Id., at Article 13 .

112. The Court was shut down in 1918, after it was called to rule over two highly political cases concerning the exclusive right for building a second inter-oceanic channel through Nicaragua granted to the United States by the Bryan-Chamorro Treaty. CARLOS José GuTIÉRREZ G., LA CORTE DE CARTAGO 137 (2009).

113. In 1921, Costa Rica, Guatemala, Honduras, and El Salvador established a regional Supreme Court to reduce the legal differences between the States. In 1922, the International Central American Tribunal was established with the power to rule over any controversy arising between them, whatever its nature or origin might be. This Tribunal was ratified by four states (El Salvador declined to ratify it), and it remained in force until 1934. Manley O. Hudson, The Central American Court of Justice, AM. J. INT'L L. 759, 783-84 (1932). In 1962, in the framework of the Organization of Central American States (ODECA), a Corte de Justicia Centroamericana was established with the power to rule over every conflict arising between the Member States. Article 14 and 15 of the Second Charter of the ODECA. Carta de la Organizacion Estados Centroamericanos (ODECA), Costa Rica-Nicar.-Hond.-El Sal.-Guat., Oct. 14, 1951, full text of the Treaty is available at http://www.rijia.org/assets/1 carta-de-la-organizacionde-la-odeca.pdf. This institution, however, was never called to decide any relevant issue. See, ORLANDO MEJÍA HERRERA, LA UNIÓN EUROPEA COMO MODELO DE INTEGRACIÓN: ANÁLISIS COMPARATIVO DEL SISTEMA DE LA INTEGRACIÓN CENTROAMERICANA 442 (2008). Finally, the idea of a regional court to pacify the region was resurrected at the beginning of the $1990 \mathrm{~s}$, during the peace negotiations of Esquipulas $I$ and $I I$ and was coupled with the need of establishing a Community law Court in the context of the creation of the SICA. 
legal field, which ended up being characterized by two main views related to regional laws and institutions.

For more than a century, the field - together with the main interests and ideology of the lawyers willing to build a Central American court-revolved more around the dream of pacifying a seemingly uniform yet utterly divided region rather than around regional economic integration. The fulfillment of such a dream, however, was not-or at least not only-related to the development of a technical and apolitical system of Community norms aimed at building a common market, but rather with the creation of institutional and legal tools able to mend all the conflicts of the region and to enforce the rule of law at the national and regional levels. ${ }^{114}$

In the early 1950s, however, the balance of power within the field was altered, and the movement related to pacification through international and constitutional law was paralleled by a project focused on economic development through international organizations. It is in this context that the Organization of Central American States (ODECA) (1951) and the Central American Common Market (CACM) (1962) were established. ${ }^{115}$ Initially, the ODECA and the CACM did not envision the establishment of judicial institutions, as the main actors of the systems believed that regional integration was a mere intergovernmental affair. ${ }^{116}$ Over time, however, the ODECA and the CACM nurtured a new generation of lawyers, whose professional orientation and interests leaned more towards developing some form of legalized and judicialized version of Central American integration.

Importantly, the two movements highlighted above-related to pacification and regional economic integration respectively - merged during the 1990s, when the present CACJ was established in the context of the reformation of the regional integration project and of the peace negotiations of Esquipulas $I$ and $I I$. In connection to this, it is of pivotal importance to mention that, during the negotiations leading to the establishment of the present CACJ, a close network of powerful lawyersthe Presidents of the Supreme Court of the Central American States-took the lead in drafting the Statute of the Court. A few years before the Court's opening, while the Central American Heads of Government were finalizing both the peace negotiations of Esquipulas and the reforms leading to the SICA, the judges of the Supreme Court had reestablished an old and highly

114. Interviews n.7, n.8.

115. Rafael A. Sanchez Sanchez, The Politics of Central American Integration 51 (2009).

116. Although, formally, the Carta de San Salvador II, in amending the ODECA, formally created a Central American Court of Justice. Carta de la Organizacion Estados Centroamericanos (ODECA), art. 2, Dec. 12, 1962, available at http://www.rijia.org/assets/1 carta-de-la-organizacion-de-la-odeca.pdf. 
respected institution of Central American legal history-the Central American Judicial Council - with the goal of bonding the judicial powers of the Central American States and of suggesting reforms aimed at smoothing out the legal differences among them. ${ }^{117}$ Hence, once Heads of Government realized that the future SICA had to also encompass the establishment of a regional (economic) court, they delegated to the judges at the Judicial Council the task of drafting the Statute of the SICA Court.

Differently from the Heads of Government, who wanted to equip the SICA with an EU-style regional economic court, the judges at the Judicial Council were part of those lawyers who envisioned Central American law as a tool for democratization and pacification. Accordingly, in drafting the Statute of the Court, they did not only create a Court specialized in building a common market, but also an institution aimed at continuing the tradition of regional judicial institutions designed to pacify and democratize the Central American region by legal means. ${ }^{118}$

In so doing, they deliberately revived the institutional make-up and ideology of the - for them-mythical Cartago Court. Similar to the old Court, the CACJ was vested with the task of: a) "representing the national conscience of Central America;" and b) "being the depository and the guardian of the values that constitute the Central American nationality." 119 Moreover, in addition to the EU-like Community Law jurisdiction requested by the Heads of Government, the judges delegated to the CACJ several competencies clearly aimed at making the CACJ an institution able to make a difference in the Central American pacification and democratization process. Most notably, the power to rule in inter-state conflicts and in separation of powers disputes within the constitutional organs of the Member States. ${ }^{120}$ Finally, once the judges finalized the proposal for the Statute of the CACJ, they sent it to the Heads of Government, who approved and ratified it without further changes.

Also in the case of the CACJ, this diachronic and actor-based analysis provides key evidence for explaining the Court's involvement in politically sensitive issues. The history prior to the establishment of the present CACJ reveals that the Court is not only a product of the legalization process triggered by the end of the Cold War, but also the resultant of several and overlapping dialectics between the different levels of structures and discourses of power that had shaped the emerging field of Central American

117. It is actually in this context that the first proposal for a CACJ aimed at fostering the process of pacification of Central America was advanced.

118. Interviews n.7, n.8, n.9.

119. Statute of the Central American Court of Justice, supra note 1, at 10.

120. See id. at 13 . 
law over time. Most notably, democratization and pacification through legal and judicial means.

Similar to the case of the CCJ, this is not a mere historical curiosity. The CACJ's involvement in politically sensitive issues is a consequence of the fact that the main structuring forces of the Central American legal fieldand accordingly the main professional interests and visions of law of the legal and political elites within such field-focused not only on economically and legally integrating the region, but also - and above all on issues related to the pacification and democratization of the Central American region. The idea of establishing a regional economic court to foster integration was, henceforth, a relatively recent occurrence that layered on top of a long-lasting discourses of ideas and power, mostly centered on pacification and democratization. This, in my view, explains the predisposition - or at least the missing reluctance-of the CACJ in getting involved with politically sensitive issues.

B. Career Paths of the Judges of the CACJ and of the CCJ and Influence in the Two Courts' Activities.

Additional evidence accounting for the involvement of the CACJ and the CCJ in politically sensitive issues is provided by the career paths of the judges eventually chosen to constitute the benches of the two Courts, by their professional networks, and by their positioning within the Central American and Caribbean legal fields.

Making sense of common cognitive and normative frameworks requires accounting for the personal ties, connections, visions of the world, and professional interests of those individuals who have guided such constructions. ${ }^{121}$ This is even more compelling with regard to weakly structured and still fragmented polities, like the Central American and the Caribbean ones, where the existence and formation of trans-national and cross-sectoral groupings of professionals are instrumental to the progressive framing of regional laws.

1. The Judges of the CCJ as a Microcosm of the Caribbean Legal Field The professional profiles of the judges eventually chosen for the bench of the CCJ constitute a microcosm of the socio-political struggles of the Caribbean legal field, including the different constructions of transnational law between English Common Law and Caribbean Community Law and the

121. See generally Antoine Vauchez, The Making of the European Union's Constitutional Foundations: the Brokering role of Legal Enterpreneurs and Networks, in TRANSNATIONAL NETWORKS IN REGIONAL INTEGRATION: GOVERNING EUROPE 1945-83 (Wolfram Kaiser et al. eds., 2010). 
opposed constituencies that characterized the legal history of the region (the older and the younger lawyers).

In addition to individuals with a clear expertise in Caribbean Community Law, ${ }^{122}$ the majority of the CCJ's judges are specialized in constitutional and public international law; two of them were even appointed as judges at the JCPC right before being called at the CCJ. Key figures in this regard are the two Presidents of the Court, Michael de la Bastide and Sir Dennis Byron. Besides being obvious supporters of the project of the CARICOM, they were both well-known members of the English-educated Caribbean legal elites, and, like them, they envisioned Caribbean Community Law not only in terms of economic law but, mostly, in terms of (national and international) human and fundamental rights. Both de la Bastide and Sir Byron are what contemporary sociology defines as members of a "transnational power elite," lawyers able to practice law across legal cultures and systems by making use of their transnational legal education and networks. $^{123}$

The very first President of the CCJ-Michael de la Bastide-was a well-known pan-Caribbean lawyer, former President of the Law Association, and former Chief Justice of Trinidad and Tobago. He graduated from Oxford in 1959/60 and became member of the Gray's Inn in London (1956); he was even appointed to the JCPC in 2004, less than three weeks before accepting the role of President of the CCJ. ${ }^{124}$ In Trinidad and Tobago, his career involved key venues of the legal and political elite: he had been Queen's Council (QC), independent Senator, a member of various government commissions, Crown Counsel in the office of the Attorney General, and, finally, Chief Justice of Trinidad and Tobago from 1995 to 2002. Most importantly, de la Bastide was known as a strong supporter of

122. Two judges of the CCJ had a clear expertise in CARICOM Law. Justice Duke Pollard (Guyana) studied at the University of London and had been the Legal Advisor of the Commonwealth Secretariat, as well as the CARICOM Secretariat. At the time of his appointment, Justice Pollard had made himself a name as an expert jurist in international law, international economic law, the Law of the Sea, the Law of Treaties, as well as general integration law and economic integration law. He was clearly meant to be the CARICOM Law expert of the bench. In 2010 Justice Pollard retired and he was replaced by a lawyer expert in international law, human rights, and CARICOM Law. Justice Winston Anderson (Jamaica), who studied law at Cambridge, received a Doctorate in Philosophy from Cambridge in 1988. He majored in International and Environmental Law. The same year he was called to the Bar of England and Wales as a Barrister of the Honourable Society of Lincoln's Inn. He also served as Dean of the Faculty of Law of the UWI. Most importantly, from 2003 to 2006 he was also appointed as General Counsel of the CARICOM Secretariat.

123. See Transnational Power Elites: The New Professionals of Governance, LaW AND SECURITY 1 (Niilo Kauppi \& Mikael R. Madsen eds., 2013).

124. Interview n.2. 
the replacement of the JCPC with a Caribbean Court of Appeal, as also revealed by his writings. ${ }^{125}$

The influence of de la Bastide in the early days of the Court is remarkable. Initially, he played a key role in setting up the newborn Court and in the appointment of the other judges to the bench, ${ }^{126}$ who, in his view, had to be first class jurists able to recognize the intricacies of the various interests at play in the Caribbean legal fields. ${ }^{127}$ In particular, de la Bastide's main mission was to make the $\mathrm{CCJ}$ the ultimate arbiter of a purely Caribbean jurisprudence. In this regard, it is probably not accidental that de la Bastidetogether with Justice Adrian Saunders, who is another member of the old English-educated legal elite ${ }^{128}$-were the two judges chosen to deliver the main judgment of the CCJ in Joseph and Boyce. The pro-human rights and anti-death penalty outcome of the case clearly represent the view of the two judges, who in their previous careers had already distinguished themselves as outspoken supporters of the need to make the present CCJ into an institution able to make a difference in the protection and enforcement of human and fundamental rights in the Caribbean.

A similarly important role was played by the second President of the CCJ, Sir Charles Dennis Byron, who, in addition to his strong Common Law background (he graduated from Cambridge, was called to the bar of the Inner Temple, pursued private practice with chambers in Saint Kitts \& Nevis and,

125. See, e.g., Michael de la Bastide, The Case for a Caribbean Court of Appeal, 5 CARIBBEAN L. REV. 401, 403 (1995).

126. The judges of the CCJ are appointed by a unique organ, the Regional Judicial and Legal Services Commission, of which the President of the CCJ is the Chairman. See Agreement Establishing the Caribbean Court of Justice, art. 5, Feb. 14, 2011, available at http://www.caribbeancourt ofjustice.org/wp-content/uploads/2011/09/ccj_agreement.pdf.

127. Other judges were experts in Caribbean Common and National Laws, as in the cases of: Justice Rolston Nelson (Trinidad \& Tobago), who, after having studied at the University of Oxford and University of London, had practiced law in Jamaica and in Trinidad \& Tobago, as well at tutored law in Jamaica and in Trinidad \& Tobago; Justice Adrian Saunders (St. Vincent and the Grenadines), who studied at the University of West Indies and at the Hugh Wooding Law School of Trinidad \& Tobago, before being appointed Chief Justice of the Eastern Caribbean Supreme Court; Justice Desiree Bernard (Guyana), who studied law at the University of London, before being appointed as Chief Justice, and Chancellor of the Judiciary of Guyana. Together with Justice de la Bastide, these three judges are part of that old elite of Caribbean lawyers that had developed a vision of Caribbean Community Law in terms of fundamental rights. In addition to experts in International Law and national Caribbean laws, the bench was completed with two judges, whose expertise was on Civil and European Law, as well as Business Law, including trusts: Justice Jacob Wit (the Netherlands), who studied law at the Vrije Universiteit of Amsterdam, and had held the position as Judge at the Joint Court of Justice of the Netherlands, Antilles and Aruba. He was clearly intended to be the civil law (and EU law) judge on the court; Justice David Hayton (England), who studied law at the Newcastle University, before ending up as law professor and Dean of the Faculty of Law of the King's College of London, combining academia and practice as a world-leading authority on the law of trusts.

128. See id. 
in 2004, was appointed to the JCPC), also brought to the Court his significant experience in Caribbean constitutional law and international human rights, himself being former Chief Justice of the Eastern Caribbean Supreme Court and former President of the United Nations International Criminal Tribunal for Rwanda. ${ }^{129}$ Since the beginning of his term, Sir Byron indicated his intention to expand the outreach of both jurisdictions of the Court toward encompassing human and fundamental rights. ${ }^{130}$ The most significant development in this regard can be found in the Maya and Myrie cases discussed above. Through these decisions, the Byron Court not only reinforced its role as ultimate arbiter of a Caribbean jurisprudence in the Appellate Jurisdiction-hence, following the steps of the de la Bastide Court — but also added an additional and more international dimension to its practices, in line with the more internationally oriented professional profile of its new President: with the Maya case, the CCJ allowed international human rights treaties to play a broader role in the Caribbean national legal orders; with Myrie, it deliberately transformed the Original Jurisdiction from a venue for CARICOM-related and economic disputes into an additional site for the protection and enforcement of human and fundamental rights for Caribbean citizens.

In conclusion, once approached from this agent-based perspective, the CCJ's proclivity for getting involved with politically sensitive issues becomes less surprising. In fact, this is a consequence of the professional expertise of the judges eventually chosen to sit on its bench, who, with two exceptions, had almost no expertise on CARICOM Law and were for the most part human rights and constitutional law lawyers.

2. The CACJ as an Extension of the National Judiciaries

As to the CACJ, of particular importance is the fact that, from its inception to the present, the Court was filled with either former Supreme Court judges or with public international law attorneys. Only a few of them were and are experts of SICA Law. ${ }^{131}$ The first batch of judges (1994-2005) was constituted by an overwhelming majority of former members of national Supreme Courts. Illustrative in this regard were the two Nicaraguan judges-

129. The Right Honourable Sir Charles Michael Dennis Byron, CARIBBEAn COURT OF Justice, http://www.caribbeancourtofjustice.org/about-the-ccj/judges/byron.

130. Interview n.1.

131. This is hardly surprising as, like the Statute of the Court, the procedure for appointing the judges of the CACJ was decided by the Presidents of the Supreme Courts of the Central American States, who made sure to be in charge of appointing the judges of the CACJ. 
Dr. Orlando Trejos Somarriba ${ }^{132}$ and Dr. Rafael Chamorro Mora ${ }^{133}$ - who were not only part of the national judiciaries but were also tightly linked to that close network of Supreme Court judges who had established the CACJ as a tool for pacifying the Central American region. Concerning the remaining members of the first group, ${ }^{134}$ a special mention must be granted to one of the two Honduran judges, Dr. Roberto Ramírez. Dr. Ramírez was the person appointed by the Central American Judicial Council to produce a preliminary study on the feasibility of the CACJ and, most likely, the one who initially suggested to make the present Court into an institutional revival of the old Cartago Court as well as an institution chiefly aimed at pacifying the Central American region. ${ }^{135}$

The tendency of filling the bench of the CACJ with either former national judges or with public international law lawyers was confirmed with the appointment of the second batch of judges (2005-2015). Here, it is worth mentioning Dr. Ricardo Acevedo Peralta, from El Salvador, who, before being selected at the CACJ, had been Professor of International Law, Minister of Foreign Affairs of El Salvador (1984-1989), member of the Permanent Court of Arbitration of the United Nations (1988-1995), member of the Salvadorian Parliament (1991-1995), member of the Central American Parliament (1986-2001), and, finally, agent of El Salvador before the InterAmerican Court of Human Rights (2003-2005). Other important figures are: Dr. Guillermo Augusto Pérez Cadalso Arias, from Honduras, who had been Professor of International Law at the Autonomous Nacional University of Honduras, and Judge of the Supreme Court of Honduras; and Dr. Darío

132. Dr. Trejos Somarriba was the former President of the Supreme Court of Nicaragua and of the Central American Judicial Council. He also played a central role in negotiating the Statute of the Court and in its inception.

133. Dr. Chamorro Mora graduated from the Central American University of Managua and had been President of the Court of Appeal and former Judge of the Supreme Court of Nicaragua as well as Secretary of the Central American Judicial Council.

134. In addition to the two Nicaraguan judges, the bench of the CACJ was composed of the following individuals. For El Salvador: Dr. Jorge Antonio Giammattei Avilés, who graduated from the Autonomous University of Guadalajara, had been Attorney at Law representing the interests of several international and Central American companies, Professor of Law at the Autonomous University of Guadalajara (among other things, he taught Customs and Central American Community Law), and judge of the Supreme and Constitutional Court of El Salvador; and Dr. Fabio Hércules Pineda, who graduated from the Faculty of Law of the University of El Salvador, and had been judge of the Constitutional Law department of the Supreme Court of El Salvador. The other judges from Honduras were Dr. Adolfo León Gómez, Professor of Mercantile Law, Political Economy and Finances in several Honduran Universities, who had been a Member of the Commission for the reformation of the Honduran judiciary, Dr. Roberto Ramirez who passed away in 1997 and was substituted by Dr. José Eduardo Gauggel Rivas, who had been Professor of Law at the University of San Pedro Sula, and Judge of the Honduran Supreme Court. Judge Gauggel Rivas. Dr. Rivas, however, quit his position in 1998.

135. See generally GUTIERREZ G., supra note 112. 
Francisco Lobo Lara, also from Honduras, who had been Professor of Law at the National Autonomous University of Honduras as well as Ambassador of Honduras at the United Nations. ${ }^{136}$ Dr. Lobo Lara repeatedly voiced the importance of the CACJ as a tool for pacifying the Central American region and for protecting and enforcing the rule of law in the national systems. ${ }^{137}$

The influence of jurists with clear expertise in constitutional and/or international law on the activity of the CACJ is remarkable, and it has inevitably led the Court to be involved with politically sensitive issues. To begin with, in many instances, the present CACJ did not hesitate in corroborating the thesis of the institutional continuity with the Cartago Court. Illustrative in this regard is the reasoning that led the CACJ to impose its jurisdiction over Costa Rica in the case Association of Custom Agents of Costa Rica v. Costa Rica. ${ }^{138}$ In this case, the CACJ asserted its power to have jurisdiction over Costa Rica by relying on the fact that, over time, the State had accepted the jurisdiction of a Central American Court in more than one instance: firstly, in 1907 (the Cartago Court), secondly in 1962 (the ODECA Court), and finally, in 1991 by ratifying the Protocol of Tegucigalpa. This reasoning, in turn, confirms that the present judges of the CACJ perceive their Court not only as an institution aimed at building a common economic space among the Central American States, but also as the continuation of a long project of regional pacification through judicial means, initiated by the Cartago Court and resurrected by the present CACJ.

The peculiar expertise and interests of the CACJ's judges also influenced Court's activity in other cases. Perhaps the most important in this regard are the Bolaños case and the three cases connected to the territorial disputes between Honduras, Costa Rica, and Nicaragua. In all of these instances, the CACJ not only showed its inclination to deal with issues of constitutional and international nature, but also showed that these topics best fit the interests and the capacities of its judges. As shown elsewhere, the CACJ has also produced several rulings dealing with the less politically salient issues of implementation and enforcement of SICA Law. ${ }^{139}$ Yet, these

136. The remaining judges were: for Nicaragua, Dr. Silvia Isabel Rosales Bolaños, a lawyer specialized in Criminal Law and Procedure, who had been Judge of the Criminal Law section of the Nicaraguan Supreme Court and an activist known for her role in the protection of women and children's rights; and Dr. Carlos Antonio Guerra Gallardo, who had been Member of the Human Rights Commission, Member of the Nicaraguan Parliament and Judge of the Nicaraguan Supreme Court. El Salvador appointed Dr. Julio Enrique Acosta Baires, a lawyer specialized in Mercantile Law, who had been Dean of the Faculty of Law and Social Sciences at the Alberto Masferrer University of El Salvador and Judge of the Supreme Court of El Salvador.

137. Francisco Dario Lobo Lara, CONFlictos ENTRE Poderes del Estado 155 (2012).

138. Case no. 87-06-08, 54 (CACJ 2008).

139. Caserta, supra note 3, at 592-600. 
judgments hardly had concrete impact on the ground and have been even criticized from many quarters for being out of touch both with the reality of the Central American process of regional integration and with the difficult political situation in which several states of the region navigate. ${ }^{140}$ Conversely, judgments like the Bolaños case-though criticized for politicizing the Court too much - or like those between Honduras, Costa Rica and Nicaragua, are generally recognized as the most important contributions of the Court both to the development of Central American Community Law and to the pacification of the Central American region.

\section{The Jurisprudence of the Two Courts as a Legitimization Strategy}

From the analysis conducted above, the involvement of the two Courts in politically sensitive issues reflects both the general structuring dynamics of the Central American and Caribbean legal fields as well as the professional profiles of the judges of the two Courts. Therefore, I argue that these politically sensitive rulings of both the CACJ and the CCJ constitute part of a legitimization strategy of the judges, who have attempted to make their Courts reflective of the various struggles at play in the Central American and Caribbean legal fields.

As to the CCJ, the judges tried to make the Court's practices palatable to the different constellations of legal elites at play in such field; most notably, to those lawyers advocating for severing the ties with the JCPC and to those who feared that by abandoning the English judicial system, the human and fundamental rights standards in the region would be curtailed. This legitimation strategy is evident in many of the cases decided by the Court. With Joseph and Boyce, the CCJ dismissed the charges of being a "hanging court" - thus silencing the critiques of some pro-JCPC lawyersand showed that it was much more than a local epigone of the English Court. This, in turn, demonstrated to the whole Caribbean legal environment that the CCJ is able and willing to become the ultimate arbiter of an indigenous jurisprudence. The decisions of the Court in Myrie and Tomlinson can also be read along these lines, as through them the $\mathrm{CCJ}$ signaled to the main stakeholders of the CARICOM that its OJ is not only a venue for large panCaribbean businesses, but also a site for individuals to seek protection of the rights granted to them by the RTC.

As to the CACJ, the judges aimed at triggering the interest of those lawyers and politicians who envisioned Central American Community Law as a tool to pacify and democratize the region. This legitimization strategy is evident in many of the cases decided by the Court. The two cases between

140. Interviews n.4, n.9. 
Nicaragua and Honduras and the one between Nicaragua and Costa Rica are clear attempts by the judges to place the CACJ at the top of the Central American legal systems and to make it into the sole and ultimate arbiter for inter-state disputes in the region. The same rationale lies behind the Bolaños case, by means of which the Court has attempted to impose its authority as the ultimate enforcer of the rule of law within the legal system of each of its Member States.

To conclude, I wish to return to the underlying theoretical discussion of this paper. In particular, the experiences of the CACJ and the CCJ show that the idea advanced by many authors, according to which recently established ICs must not be involved with politically sensitive disputes to avoid political pushbacks, ${ }^{141}$ may not always be the right strategy for ICs entrenched in socio-political contexts where national understandings of legality and the overall ideological and professional preferences of powerful legal elites are not strongly linked to regional integration and economic law. In Weberian terms, ${ }^{142}$ in their practices, the CACJ and the CCJ did not develop some kind of formal and neutral legal rationality àl'européenne, but instead aimed at producing substantively thick regional legal systems with the goal of overcoming the structural limitation of the national ones and, eventually, of legitimizing the two regions in the eyes of the major stakeholders of their systems.

Finally, both the CACJ and the CCJ have become involved with politically sensitive issues because, at their roots, they are not - or at least not only-EU-style ICs, but the international manifestation of national and regional processes of social and legal reproduction encompassing the various forms of legality that have characterized the Central American and Caribbean social fields over time.

\section{CONCLUSIONS}

On the side of developing technical and apolitical bodies of Community Law, both the CACJ and the CCJ have come to rule over politically sensitive issues, ranging from freedom of movement to issues of mega-politics. In doing so, both Courts have expanded the reach of their competencies, emphasizing the respect of fundamental rights, democracy, rule of law, and good governance. This paper has sought to explain the behavior of these two Courts and the reasons why they have avoided significant pushbacks by their Member States. It has done so by analyzing the trans-historical trajectories of the main structuring forces of the Central American and Caribbean social

141. Alter, supra note 12; Madsen, supra note 12.

142. See generally KiERAN AlLEN, MAX WEBER: A CRITICAL INTRODUCTION (2004). 
and legal fields and the professional paths of the judges eventually chosen to sit on the benches of the two Courts. Through such analysis, the article shows that both the CACJ and the CCJ were only partially established to pursue regional economic integration and that the interests of the agents that participated in their creation as well as of their judges revolved mostly around pacification and democratization in Central America and decolonization through the development of a system of human and fundamental rights in the Caribbean. In turn, these interests have significantly impacted the two Courts' institutional outlook and practices, making them willing to engage into politically sensitive issues rather than act as mere regional economic courts.

These findings have important theoretical consequences. Most notably, ICs cannot be explained solely by looking at the moment in which they were established (as, for the most part, delegation theories do) and that they cannot be constrained in fixed and static definitions provided a priori (i.e. OldStyle or New-Style, economic or human rights ICs) but that each singular IC is the consequence of highly differentiated socio-political and historical contexts which respond not only to general global forces but also-if not above all - to national and regional conditions and interests. ICs are, hence, not unitary, homogenous, and discrete units influenced by rational behavior and institutional design, but are instead social facts to be investigated as a product of the societies in which they are embedded, as they are the result of broad structural developments, collective (most times adversarial) human action, professional and group interests, socialization, and identity formation. ${ }^{143}$ In other words, ICs are both deeply rooted in national legal cultures and power positions, while at the same time have developed specific international traits.

143. Similar to what is claimed in Fredrik Söderbaum, The Political ECONOMY of REGIONALISM: THE CASE OF SOUTHERN AFRICA 31 (2004). 
VII.APPENDIX

\begin{tabular}{|c|}
\hline Interviews Cited \\
\hline Interview n.1, October 21, 2013 at 10:00 am with a Trinidadian Lawyer \\
\hline Interview n.2, October 21,2013 at 3:00 pm with a Judge of the CCJ \\
\hline $\begin{array}{l}\text { Interview n.3, November 6, } 2013 \text { at 9:00 am with a Barbadian } \\
\text { Government Official }\end{array}$ \\
\hline Interview n.4, July 9, 2014 at 9:30 am with a Nicaraguan Professor of Law \\
\hline $\begin{array}{l}\text { Interview n.5, July } 10,2014 \text { at } 11: 00 \text { am with a Member of the } \\
\text { Administrative Personnel of the CACJ }\end{array}$ \\
\hline Interview n.6 July 10, 2014 at 5:30 pm with a Nicaraguan Legal Official \\
\hline Interview n.7, July 10, 2014 at 5:30 pm with a Nicaraguan Legal Official \\
\hline Interview n.8, July 12, 2014 at 11:00 am with a Judge of the CACJ \\
\hline $\begin{array}{l}\text { Interview n.9, July 17, } 2014 \text { at 11:00 am with a Salvadorian Professor of } \\
\text { International and Central American Law }\end{array}$ \\
\hline
\end{tabular}

